\title{
Efektifitas Produksi Krupuk pada Home Industri Di Sidoarjo
}

\author{
Ribangun Bamban Jakaria ${ }^{1}$, Mulyadi ${ }^{2}$ \\ ribangunbz@umsida.ac.id \\ Univeritas Muhammadiyah Sidoarjo
}

\begin{abstract}
Abstrak: Pelaku usaha mikro kecil dan menengah hal yang menghambat tumbuh kembangnya usaha adalah kompetisi dan kemampuan manajerial serta pengelolaan produksi. Kondisi ini disebabkan karena keterbatasan modal yang dimiliki serta keseriusan dalam berusaha. Hal ini dialami oleh bu heni selaku produsen Krupuk kemasan, beliau memulai bisnis kecilkecilan dengan membeli krupuk curah yang telah di goreng kemudian dikemas secara mandiri dengan plastik kiloan, dan dipasarkan di sejumlah tempat. Permasalahan yang dimiliki bu heni selaku Mitra 1 adalah proses pengadaan krupuk dilakukan dengan membeli pada pihak ke dua kemudian dikemas secara mandiri di rumah namun proses pengemasannya masih dilakukan secara sederhana yaitu dengan menyalakan lilin kemudian plastik di didekatkan untuk dapat merekatkan plastik kemasan tersebut, kemudian kemasan yang telah dilakukan tidak ada merk atau nama dari hasil pengemasan tersebut, sehingga produk yang dihasilkan dan kemudian dipasarkan tidak memiliki nama atau brand produk yang menyebabkan harga jualnya sangat murah, dengan permasalahan pada mitra 1 tersebut, maka solusi yang ditawarkan adalah adanya merk dagang produk kemasan krupuk dan alat pengemas produk kemasan krupuk. Permasalahan pada mitra 2 adalah proses display produk hasil penggorengan jajanan, karena belum maksimalnya proses pemisahan minyak dan jajanan pasca penggorengan menyebabkan saat display masih banyak minyak yang melekat, sehingga bagi pelanggan yang memiliki penyakit tertentu akan menghindari makan makanan hasil penggorengan mitra, permasalahan berikutnya adalah tidak adanya identitas warung yang menerangkan identitas pemilik dan nama usahanya, sehingga sulit untuk memberikan identitas kepada pelanggan yang belum kenal, sehingga solusi atas permasalahan pada mitra 2 yaitu pembuatan tempat display gorengan yang inovatif dan higenish serta nama identitas usaha pak Umar khasan
\end{abstract}

Kata kunci : Pengepres plastik, papan nama, peniris gorengan, peningakatan produktifitas

\section{ANALISIS SITUASI}

Bagi sebagian pelaku usaha UMKM di sejumlah tempat di sidoarjo di lakukan oleh ibu-ibu yang memiliki perkerjaan tetap, artinya adalah usaha yang dilakukan hanya meruapakan usaha sambilan, sebagai pengisi waktu luang. (Rosid \& Jakaria, 2016) Di dalam beberapa literasi hal ini tentu akan menyulitkan pertumbuhan usaha yang dilakukan, mengingat usaha atau bisnis, seharusnya dilakukan secara sungguh-sungguh dan dengan manajemen waktu yang baik. Bu Heni adalah pemilik usaha krupuk yang merupakan mitra 1 
adalah memiliki pekerjaan sebagai tenaga pendidik di sekolah Play Group di kelurahan Porong kec. Porong kab. Sidoarjo, sementara suami adalah seorang karyawan swasta di salah satu perusahaan PMDN di daerah Pasuruan. Dengan melihat latar belakang pelaku usaha maka dapat dipastikan bahwa bisnis yang dilakukan oleh mitra adalah usaha sambilan yang dilakukan setelah pekerjaan utama selesai dilakukan. Namun terlepas dari itu, bahwa usaha apapun yang dilakukan seharusnya dilakukan secara serius sehingga nantinya akan memberikan nilai yang baik.

Mitra 1 adalah pelaku usaha pengemasan krupuk yang didasari karena ada pihak lain yang memproduksi krupuk mentah, dikeringkan dan di goreng, namun dengan keterbatasan modal yang dimiliki oleh mitra maka proses pengemasan hanya dilakukan dengan peralatan sederhana dengan menggunakan lilin untuk merekatkannya, dan hasilnya pengemasan kurang baik. sementara pengemasan yang dimiliki belum memiliki nama produk dan identitas lain atas produk yang dimiliki sehingga kurang menarik untuk dipasarkan ke pelanggan. Dengan mempertahankan proses produksi yang dilakukan secara sederhana dan dengan tidak adanya labeling pada kemasaan menjadikan mitra 1 tidak dapat berkopentisi untuk peningkatan nilai jual produk yang di hasilkan, sehingga dimungkinkan akan menurunkan kinerja (performance) usaha yang dijalankan.

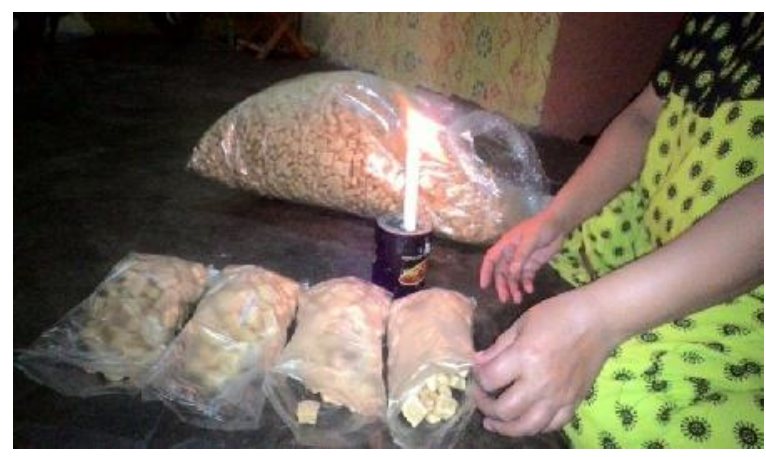

Gambar 1. Cara pengemasan krupuk yang dilakukan secara manual

Sementara usaha yang dijalankan pak umar khasan yang merupakan mitra 2 adalah usaha berjualan kopi, gorengan dan krupuk serta makananan lainnya yang membuka tempat usaha di sekitar kampus 2 di daerah gelam candi Sidoarjo, hal ini dilakukan untuk pemenuhan kebutuhan akan makanan kecil bagi pelanggannya dan mayoritas pelanggannya adalah mahasiswa Universitas Muhammadiyah Sidoarjo, khususnya di Kampus 2. 


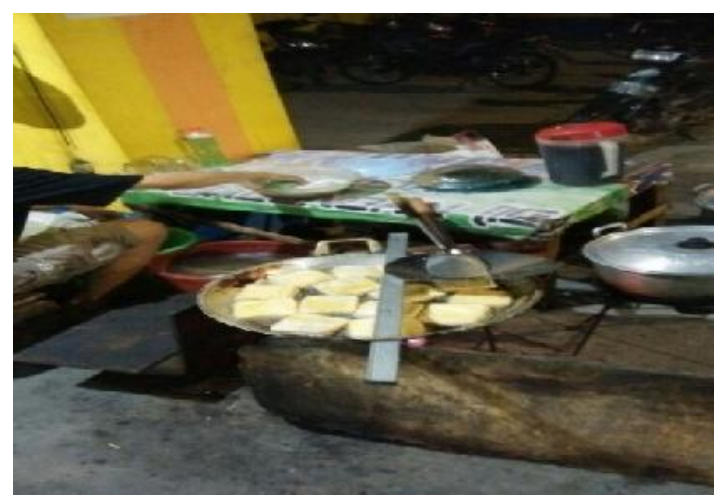

Gambar 2. Proses penggorengan dan penirisan pasca menggoreng

Karena mayoritas pelanggannya adalah dosen dan mahasiswa, maka higenitas dan identitas pemiliki adalah penting untuk dimiliki.

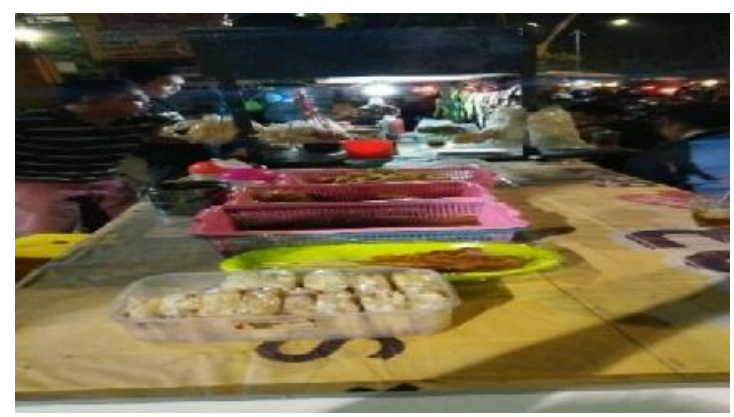

Gambar 3. Display jajanan mitra

\subsection{Permasalahan Mitra}

Dengan memperhatikan kondisi mitra 1 tersebut, maka permasalahan yang muncul adalah perekatan yang dilakukan dengan menggunakan lilin sehingga hasil perekatannya kurang maksimal dan hasil yang baik, sementara permasalahan lainnya adalah tidak adanya nama identitas pada produk yang berupa merk sehingga dampak atas ketidaksempurnaan tersebut maka berdampak pada proses produksi dan penjualanan. Proses produksi yang kurang efisien serta belum maksimalnya hasil penjualan memungkinkan akan menurunkan kinerja usaha yang dijalankan oleh mitra 1 .

Dengan banyaknya pelanggan yang berlatar belakang dosen dan mahasiswa maka higenisitas adalah faktor utama dalam penyajian makanan yang dilakukan oleh mitra, sehingga permasalahan yang ada pada mitra 2 adalah hasil penirisan pasca penggorengan yang dilakukan oleh mitra diyakini tidak maksimal sehingga pada saat penirisan pasca pengorengan maka pada saat di display harus di lakukan penirisan ulang, sehingga hasil yang diperoleh gorengan yang terbebas dari minyak secara sempurna. Permasalahan lainya adalah identitas tempat penjualan yang tidak dimiliki oleh mitra, sehingga sulit 
untuk mengidentifikasi keberadaan tempat penjualan mitra 2.

\section{METODE PELAKSANAAN}

Kegiatan pertama yang dilakukan dalam Program Pengabdian kepada Masyarakat adalah dengan melakukan kunjungan ke lapangan dengan melihat langsung kondisi dan permasalahan yang dihadapi mitra. Selanjutnya setelah program PKM ini disetujui, maka tim pengusul melakukan diskusi untuk membuat perencanaan perioritas yang berupa nama kegiatan serta waktu pelaksanaan. (Kotler dan Amstrong, 2001) Masing-masing kegiatan terdapat penanggungjawab dan akan mengevaluasi kesesuaian kegiatan dengan yang telah direncanakan. Selain itu selama pelaksanaan program PKM, tim pengusul selalu berkoordinasi dengan Mitra sehingga dalam proses pelaksanaan program, Mitra memahami dan dapat menjalankan secara mandiri atas teknologi yang ditransfer melalui pelatihan dan pendampingan usaha. Untuk memastikan pelaksanaan program berjalan dengan baik, maka tim pengusul selalu melakukan evaluasi secara bertahap, guna memastikan bahwa tahapan yang dilalui berjalan dengan baik (Permana et al., 2017). Sehingga bukan hanya kerjasama tim pengusul saja yang menjadi perioritas tetapi kerjasama Mitra juga penting. Karenanya potensi masing-masing anggota tim dapat dioptimalkan sesuai dengan bidang kepakarannya. Sehingga hubungan Mitra dengan tim Pengusul adalah Mitra berkontribusi dalam memberikan gambaran permasalahan sehingga pengusul dengan jelas menawarkan solusi sehingga akan memberikan manfaat bagi Mitra.

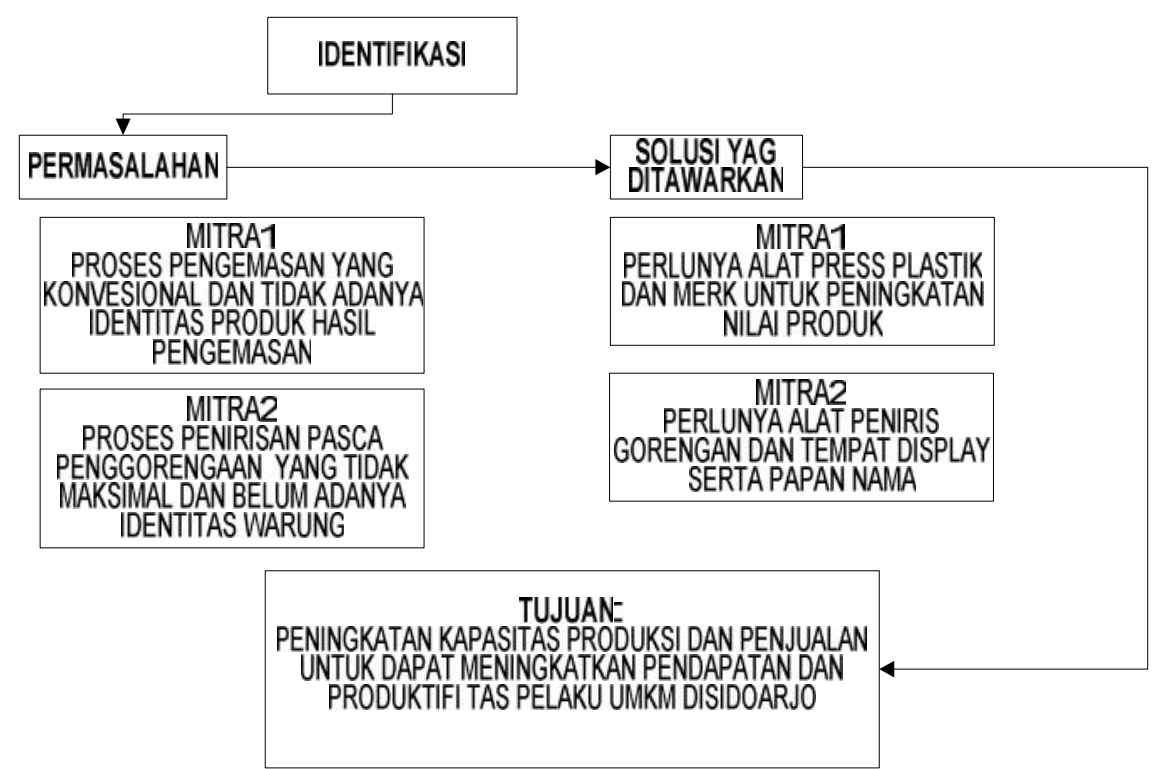

Gambar 3. Tahapan pelaksanaan PKM 
Ribangun Bamban Jakaria ${ }^{1}$, Mulyadi ${ }^{2}$

\section{HASIL DAN PEMBAHASAN}

1. Pengadaan kebutuhan mitra

Hal ini bertujuan untuk memenuhi kewajiban yang harus dipenuhi oleh pengusul atas mitra yang meliputi, pembuatan alat perekat plastik yang fungsi sebagai alat perekat plastik kemasan krupuk hasil produksi mitra, sehingga proses produksi yang dilakukan akan semakin efektif dengan merubah pola perekatan kemasan yang menggunakan lilin sekarang menggunakan alat perekat plastik.

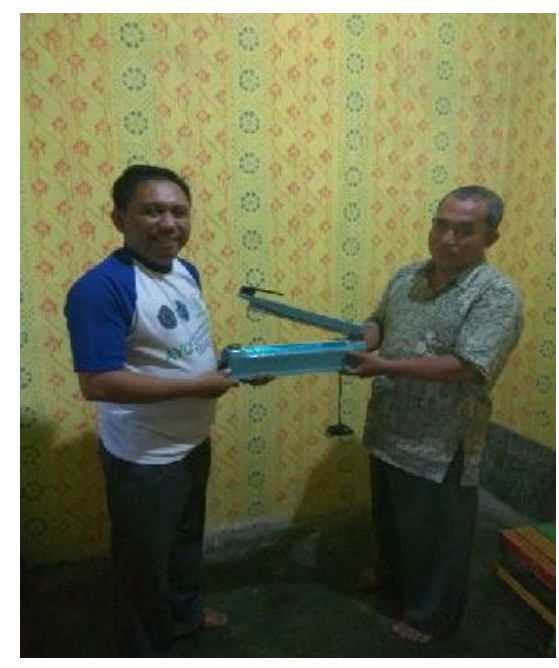

Gambar 4. Penyerahan alat perekat plastik kepada mitra
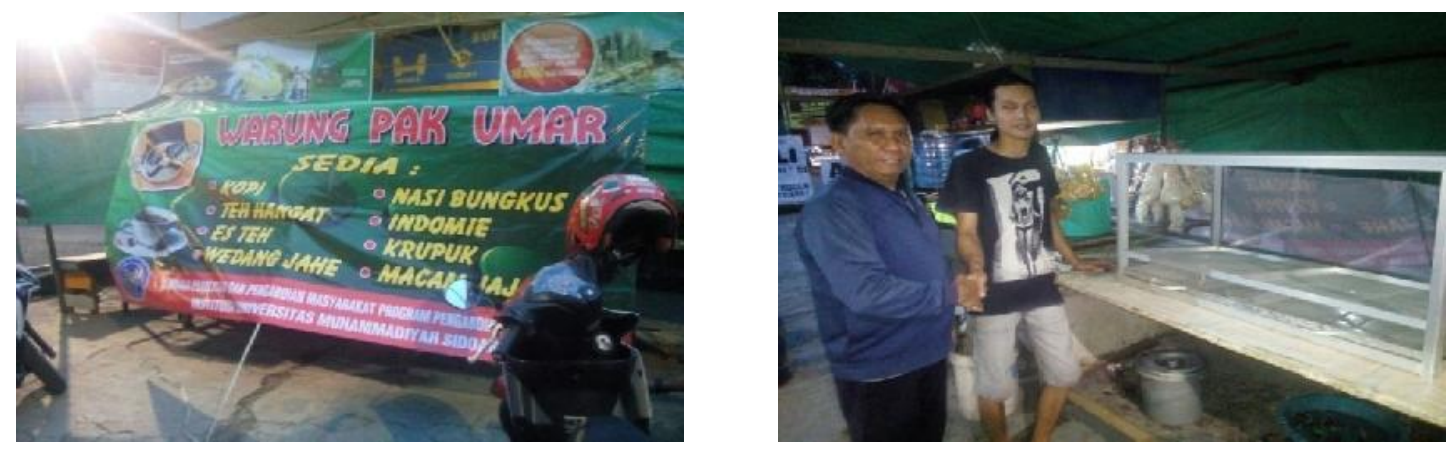

Gambar 5 dan 6. Penyerahan banner nama warung dan display jajanan

\section{PENUTUP}

\section{Kesimpulan}

Memberikan mesin perekat plastik adalah salah satu upaya yang dilakukan untuk menyelesaikan masalah yang dilakukan oleh mitra 1. Sehingga dengan adanya alat perekat plastik tersebut, proses pengemasan yang awalnya dilakukan dengan menggunakan lilin, dengan adanya alat perekat plastik tersebut, akan memberikan kemudahan dalam melakukan 
proses produksi, sehingga akan memberikan dampak positif atas waktu produksi dan mekanisme perekatan yang dilakukan selama ini.

Tempat display produk jajanan yang selama ini di gunakan oleh mitra berupa kotak plastik secara umum tidak memberikan dampak posiitif kepada pelanggan atas produk yang dijajakan, namun dengan merubah desain dan tempat display produk jajanan tersebut, pelanggan akan memberikan respon positif atas produk yang dijajakan, hal ini disebabkan bahwa produk yang dijajakan kini akan terlihat bersih dan higenis.

Bahwa permasalahan yang timbul pada mitra dan solusi yang ditawarkan bukan merupakan permasalahan secara keseluruhan tetapi sebagian dari permasalahan yang ada di mitra, namun dengan mengambil satu dari beberapa permasalahan tersebut termasuk memberikan solusi atas maka kita dapat berperan atas penyelesaian masalah tersebut,

Guna kesinambungan program abdimas ini maka disarankan memasukkan beberapa permasalahan yang terjadi di mitra sebagai program abdimas selanjutnya, diantaranya adalah terkait penyediaan bahan baku, order dan delevery serta kualitas jajanan dan manajemen usaha, baik pada mitra 1 dan 2 .

\section{DAFTAR PUSTAKA}

Jakaria, R. B. (2017). Inovasi Pembersihan Bulu Ayam Pada Pelaksanaan Abdimas

Dikelurahan Porong. Research report, UMM

Jakaria, R. B. (2017). Pemberdayaan Usaha Jajanan Pasar Guna Peningkatan Industri Kecil

Menengah Di Sidoarjo, Dedikasi vol 14, UMM

Kottler. (2007). Manajemen Pemasaran, Prehanllindo, Jakarta

Kotler, Philip. (2001). Manajemen pemasaran di Indonesia : Analisis, Perancangan,

Implementasi dan pengendalian, Salemba Empat, Jakarta

Kotler dan Amstrong. (2001). Prinsip-Prinsip Pemasaran Jilid I. Erlangga.

Permana, E. P., Mujiwati, E. S., Sahari, S., Santi, N. N., Damariswara, R., Mukmin, B. A., ...

Saidah, K. (2017). Pelatihan Penulisan Karya Ilmiah Untuk Guru Sekolah Dasar Pada

Anggota Gugus 1 Kecamatan Ringinrejo Kabupaten Kediri. Ppm, 1(1), 52-68. Retrieved from http://ojs.unpkediri.ac.id/index.php/

Rosid, M. A., \& Jakaria, R. B. (2016). Implementasi Framework Twitter Bootstrap Dalam

Perancangan Aplikasi Penerimaan Mahasiswa Baru Berbasis Web. Kinetik, 1(3), 129.

https://doi.org/10.22219/kinetik.v1i3.121

Stanton,William J. (2001). Prinsif Pemasaran, Erlangga, Jakarta 